Paweł Lewandowski, Zadania sędziego w procesach pierwszej instancji Sądu Diecezjalnego w Tarnowie w latach 1945-1983, [w:] Struktura i działalność Sądu Diecezjalnego w Tarnowie w latach 1945-1983, red. Robert Kantor, Kraków 2019, s. 21-47.

DOI: http://dx.doi.org/10.15633/9788374387309.03

KS. PAWE LeWANDOWSKI

Katolicki Uniwersytet Lubelski Jana Pawła II

\title{
Zadania sędziego \\ w procesach pierwszej instancji Sądu Diecezjalnego w Tarnowie w latach 1945-1983
}

Na kartach Pierwszego Listu do Koryntian Święty Paweł Apostoł pisał:

Czy odważy się ktoś z was, gdy zdarzy się nieporozumienie z drugim, szukać sprawiedliwości u niesprawiedliwych, zamiast u świętych? Czy nie wiecie, że święci będą sędziami tego świata? A jeśli świat będzie przez was sądzony, to czyż nie jesteście godni wyrokować w tak błahych sprawach? Czyż nie wiecie, że będziemy sądzili także aniołów? O ileż przeto więcej sprawy doczesne! Wy zaś, gdy macie sprawy doczesne do rozstrzygnięcia, sędziami waszymi czynicie ludzi za nic uważanych w Kościele! Mówię to, aby was zawstydzić. Bo czyż nie znajdzie się wśród was ktoś na tyle mądry, by mógł rozstrzygać spory między swymi braćmi? A tymczasem brat oskarża brata, i to przed niewierzącymi ${ }^{1}$.

Powyższy passus potwierdza, że już w czasach apostolskich wierzący w Chrystusa mieli świadomość tego, że spory powstające wewnątrz ich wspólnoty, zarówno w sprawach „duchowych”, jak i „doczesnych”, należy rozstrzygać we własnym zakresie, w sposób niezależny od władzy państwowej. Naturalnie, sposoby rozpatrywania tych sporów zmieniały się w ciągu wieków, na co wpływ miały z jednej strony nakazy etyczne

1 Kor 6, 1-6. 
zawarte w Nowym Testamencie, z drugiej zaś określone formy jurydyczne zaczerpnięte $\mathrm{z}$ różnych systemów prawa, szczególnie $\mathrm{z}$ prawa rzymskiego ${ }^{2}$.

Cel niniejszego artykułu stanowi analiza zadań sędziego w procesach pierwszej instancji Sądu Diecezjalnego w Tarnowie w latach 1945-1983. Zakres temporalny podejmowanego zagadnienia suponuje akty normatywne, do których stosowania zobligowani byli sędziowie tego sądu. Za podstawowe źródła prawa w materii kościelnego prawa procesowego uznać należy: Codex Iuris Canonici z 1917 roku³ oraz Instrukcję Świętej Kongregacji do spraw Dyscypliny Sakramentów Provida Mater Ecclesia Z $1936 \mathrm{roku}^{4}$.

\section{Pojęcie urzędu sędziego kościelnego}

Ustawodawca powszechny nie wypracował legalnej definicji pojęcia iudex ecclesiasticus, jednak na podstawie poszczególnych dyspozycji zawartych w CIC 1917 można wskazać przymioty niezbędne dla osoby sprawującej ten urząd. Znaczącą pomoc w określeniu funkcji sędziego stanowią także definicje, jakie wykształciła nauka prawa kanonicznego. Próby zdefiniowania pojęcia iudex ecclesiasticus uznać należy za kluczowe dla przedstawienia konstytutywnych elementów urzędu sędziego kościelnego 5 .

2 Por. J. Krukowski, Wprowadzenie, w: Komentarz do Kodeksu Prawa Kanonicznego, t. 5, ks. VII, Procesy, red. J. Krukowski, Poznań 2007, s. 8; A. Fajęcki, Sądownictwo kościelne, w: Podręczna encyklopedia kościelna, t. 35-36, red. J. Archutowski i in., Warszawa 1912, s. $85-86$.

3 Por. Codex Iuris Canonici, Pii X P.M. iussu digestus, Benedicti P. xv auctoritate promulgatus, „Acta Apostolicae Sedis” [dalej: AAs] 9 (1917) pars II, s. 1-593 [dalej: CIC 1917], szczególnie księgę IV - De processibus.

4 Por. Sacra Congregatio de Disciplina Sacramentorum, Instructio servanda a tribunalibus dioecesanis in pertractandis causis de nullitate matrimoniorum Provida Mater Ecclesia, AAS 28 (1936), s. 313-372 [dalej: PME]. W materii kościelnego procesu małżeńskiego w analizowanym okresie obowiązywały także następujące dokumenty: Sacra Romana Rota, Normae S. Romanae Rotae Tribunalis, AAS 26 (1934), s. 449-491; Suprema Sacra Congregatio Sancti Officii, decretum „Qua singulari” de quibusdam cautelis adhibendis in causis matrimonialibus impotentiae et inconsummationis, AAS 34 (1942), s. 200-202; Sacra Congregatio de Disciplina Sacramentorum, Instructio de competentia iudicis in causis matrimonialibus ratione quasi-domicilli, AAS 22 (1930), s. 168-171.

5 Por. S. Pikus, Niezawisłość sędziego kościelnego, Lublin-Sandomierz 2009, s. 36-37. 
Franciszek Bączkowicz, za Francisco Xaverem Wernzem, definiuje sędziego kościelnego jako kapłana wyposażonego w jurysdykcję kościelną zakresu zewnętrznego dla rozpoznania zarówno spraw cywilnych, jak i karnych ${ }^{6}$. Johannes Baptist Sägmüller zauważa, że jurysdykcja ta może mieć charakter ogólny lub specjalny ${ }^{7}$. Dla Matthaeusa Conte a Coronaty iudex ecclesiasticus to kapłan nienaruszonej sławy, biegły w prawie kanonicznym, powołany przez miejscowego ordynariusza do rozsądzania sporów między wiernymi ${ }^{8}$. W ocenie Tadeusza Pieronka sędzia kościelny jest osobą urzędową, obdarzoną jurysdykcją do rozpatrywania i rozstrzygania sporów zgodnie z przepisami prawa kanonicznego'. Wszystkie powyższe definicje wskazują na zasadnicze elementy pojęcia urzędu sędziego kościelnego. Jest to urząd publiczny, normowany prawem kanonicznym, ustanowiony dla wykonywania władzy sądowniczej. Istotnym zadaniem sędziego kościelnego jest rozpatrywanie, czyli wyjaśnianie spraw wnoszonych do trybunału, oraz ich rozstrzyganie, czyli wydawanie decyzji sędziowskich na podstawie określonych przepisów prawa oraz wiedzy i sumienia sędziego ${ }^{10}$.

${ }^{6}$ Por. F. Bączkowicz, Prawo kanoniczne. Podręcznik dla duchowieństwa, t. 3, wyd. 3, Opole 1958, s. 22. W podobny sposób definiuje: J. E. Metz, Judges (Canon Law), w: New Catholic Encyclopedia, Vol. 8, ed. editorial staff of the Catholic University of America, San Francisco-Toronto-London-Sydney 1967, s. 18-19.

7 Por. J. B. Sägmüller, Judge, Ecclesiastical (Judex ecclesiasticus), w: The Catholic Encyclopedia. An International Work of Reference on the Constitution, Doctrine, Discipline, and History of the Catholic Church, Vol. 8, ed. Ch. G. Herbermann i in., New York 1910, s. 545.

${ }^{8}$ Por. M. Conte a Coronata, Compendium Iuris Canonici. Ad usum scholarum, Vol. 1, ed. 2, Taurini 1942, s. 214.

9 Por. T. Pieronek, Normy ogólne kanonicznego procesu sądowego, cz. 1, Warszawa 1970, s. 89 .

${ }^{10}$ Por. P. Gricewicz, Zadania sędziego kościelnego w sprawach o nieważność matżeństwa, „Roczniki Nauk Prawnych” 8 (1998), s. 166. Analizując łacińskie słowo iudex oraz polskie słowa „sąd” i „sądzič", Paweł Gricewicz wskazuje na zasadnicze cechy urzędu iudex ecclesiasticus - są to: 1) element postępowania - ciąg czynności polegający na rozpatrywaniu określonej wątpliwości; 2) element osobistego rozważania, analizowania przedłożonych argumentów; 3) element osobistej decyzji sędziego, która jest aktem woli upoważnionej do wydania wyroku z urzędu lub na wniosek zainteresowanych; 4) element skutków formalno-prawnych (por. P. Gricewicz, Zadania sędziego kościelnego..., dz. cyt., s. 164). Por. F. Bersini, La figura del giudice ecclesiastico nel discorsi del Papa, „Il Diritto Ecclesiastico” 97 (1986), s. 629-640; J. B. Sägmüller, Judge, Ecclesiastical..., dz. cyt., s. 545-547; M. Greszata-Telusiewicz, Sędzia. I. W prawie kanonicznym, w: Encyklopedia katolicka, t. 18, red. E. Gigilewicz, Lublin 2013, kol. 80-81. 
Paweł Lewandowski

Przedstawiając kategorie sędziów kościelnych, trzeba podkreślić, że w literaturze funkcjonuje kilka uznanych klasyfikacji biorących pod uwagę określone cechy ${ }^{11}$. Z punktu widzenia analizowanej w niniejszym artykule materii za istotne uznać należy rozróżnienia:

- ze względu na rolę, jaką sędzia odgrywa w procesie - wyróżnia się sędziego głównego (iudex principalis) oraz sędziów pomocniczych (iudices auxiliares). Sędzia główny kieruje całym procesem, sędziowie pomocniczy natomiast wykonują wybrane czynności procesowe zlecone przez sędziego głównego. Iudices auxiliares to: audytor, zwany instruktorem (iudex auditor seu instructor actorum), oraz relator, zwany ponensem (iudex relator seu ponens). Sędzia główny może być z kolei jednoosobowy (iudex singularis) lub kolegialny (iudex collegialis), przy czym kolegium składa się zazwyczaj z 3 lub 5 sędziów ${ }^{12}$;

- ze względu na sposób powołania na urząd - wyróżnia się sędziów synodalnych (iudices synodales), zatwierdzanych na synodzie diecezjalnym, oraz sędziów prosynodalnych (iudices pro-synodales), mianowanych poza synodem ${ }^{13}$;

- ze względu na instancję - wyróżnia się sędziów pierwszej, drugiej i trzeciej instancji ${ }^{14}$.

${ }^{11}$ Dla przykładu: wypełniane zadanie, pochodzenie jurysdykcji, rodzaj jurysdykcji, sposób powołania na urząd, przedmiot rozstrzyganego sporu itd.

${ }_{12}$ Por. T. Pieronek, Normy ogólne..., dz. cyt., s. 91. Zgodnie z dyspozycją ustawodawcy kodeksowego kolegium 3 sędziów orzeka w sprawach dotyczących ważności wyższych święceń i małżeństwa, spornych o prawa i majątek kościoła katedralnego oraz karnych dotyczących pozbawienia beneficjum nieusuwalnego lub wymierzenia ekskomuniki (can. $1576 \$ 11^{\circ}$ : „Causae contentiosae de vinculo sacrae ordinationis, et matrimonii, vel de iuribus aut bonis temporalibus cathedralis ecclesiae; itemque criminales in quibus res est de privatione beneficii inamovibilis aut de irroganda vel declaranda excommunicatione, tribunali collegiali trium iudicum reservantur"). Kolegium 5 sędziów rozpoznaje natomiast pozostałe sprawy karne, za które prawo przewiduje depozycję, wieczyste pozbawienie stroju duchownego lub degradację (can. $1576 \$ 12^{\circ}$ : „Causae vero quibus agitur de delictis quae depositionis, privationis perpetuae habitus ecclesiastici, vel degradationis poenam important, reservantur tribunali quinque iudicum").

${ }^{13}$ Zgodnie z can. 387-388 sędziów synodalnych proponuje biskup, a zatwierdza synod. W miejsce zmarłego lub zrzekającego się urzędu sędziego, usuniętego z ważnych przyczyn lub po upływie 10 lat od nominacji na synodzie, jeśli synod nie został w tym czasie zwołany, nowego sędziego mianuje biskup po zasięgnięciu opinii kapituły katedralnej.

${ }^{14}$ Por. J. E. Metz, Judges..., dz. cyt., s. 18. 
Zgodnie z dyspozycją zawartą w can. $1574 \$ 1$ w każdej diecezji należy ustanowić od 4 do 12 sędziów synodalnych lub prosynodalnych $\mathrm{z}$ władzą delegowaną przez miejscowego ordynariusza, którą otrzymują z chwilą mianowania na synodzie diecezjalnym lub poza nim ${ }^{15}$. Ustawodawca kodeksowy wymaga, aby byli to prezbiterzy o wypróbowanym życiu, biegli $\mathrm{w}$ prawie kanonicznym, mogą pochodzić $\mathrm{z}$ innej diecezji ${ }^{16}$. Za niezdolnych do pełnienia tego urzędu uznaje się zatem: 1) wiernych świeckich; 2) nieochrzczonych; 3) apostatów, heretyków, schizmatyków po wyroku skazującym; 4) pozbawionych używania rozumu; 5) duchownych ekskomunikowanych, suspendowanych i z nałożonym interdyktem osobistym, po wyroku skazującym lub stwierdzającym; 6) duchownych publicznie przystających do akatolickiego związku religijnego; 7) podległych infamii prawnej; 8) duchownych deponowanych, degradowanych oraz pozbawionych na zawsze prawa do stroju duchownego ${ }^{17}$.

\section{Zakres władzy sądowniczej Kościoła}

W celu analizy zadań sędziów Sądu Diecezjalnego w Tarnowie w procesach pierwszej instancji w latach 1945-1983 konieczne staje się precyzyjne określenie zakresu władzy sądowniczej Kościoła. Ustawodawca w can. 1553 postanawia, że na mocy własnego i wyłącznego prawa sądownictwu kościelnemu podlegają 3 kategorie spraw ${ }^{18}$.

Do pierwszej zaliczyć należy sprawy o rzeczy duchowe lub ściśle z nimi złączone $^{19}$. Za rzeczy duchowe uważa się wszystko, co związane $\mathrm{z}$ wiarą i moralnością, sakramentami i sakramentaliami, kultem Bożym, dyspensowaniem od ślubów i przyrzeczeń, urzędami kościelnymi, prawami

${ }_{15}$ Por. T. Pawluk, Kanoniczna praktyka procesowa $w$ sprawach matżeńskich, Warszawa 1975, s. 63-65.

${ }^{16}$ Can. $1574 \$ 1$ : „In qualibet dioecesi presbyteri probatae vitae et in iure canonico periti, etsi extradioecesani, non plures quam duodecim eligantur ut potestate ab Episcopo delegata in litibus iudicandis partem habeant; quibus nomen esto iudicum synodalium aut pro-synodalium, si extra Synodum constituuntur".

${ }^{17}$ Por. F. Bączkowicz, Prawo kanoniczne, dz. cyt., s. 22-23.

${ }^{18} \mathrm{O}$ zasadach działania sądów kościelnych por. H. Jone, Commentarium in Codicem Iuris Canonici, Vol. 3, Paderborn 1955, s. 55-76; M. Fąka, Normy ogólne kanonicznego procesu sądowego, cz. 2, Warszawa 1978, s. 11-54.

19 Can. $1553 \$ 11^{\circ}$ : „Ecclesia iure proprio et exclusivo cognoscit: De causis quae respiciunt res spirituales et spiritualibus adnexas". 
Paweł Lewandowski

i obowiązkami duchownych, właścicielami beneficjów i zakonnikami, egzempcją i jurysdykcją kościelną. Do rzeczy ściśle związanych ze sprawami duchowymi natomiast zalicza się m.in. kolatorstwo (prawo do obsadzania beneficjów), kościelne dochody, dziesięciny ${ }^{20}$.

Drugą kategorię stanowią przekroczenie ustaw kościelnych, a także wszystkie sprawy związane $\mathrm{z}$ grzechem, $\mathrm{w}$ takim zakresie, $\mathrm{w}$ jakim dotyczy to określenia winy i nałożenia kar kościelnych ${ }^{21}$. Ponieważ ustawy kościelne może wydawać jedynie Kościół, oczywiste jest, że tylko on może sądzić ich przekroczenia oraz orzekać o skutkach ich naruszenia. Ponadto Kościół, jako stróż prawa Bożego i moralności, jest uprawniony do sądzenia wszystkich spraw, nawet doczesnych, w sposób pośredni, a więc o tyle, o ile noszą na sobie znamię grzechu. Gdy wymaga tego jego dobro publiczne, może on także w zakresie zewnętrznym orzekać o winie lub wymierzać kary kościelne, z zachowaniem określonych norm ${ }^{22}$.

Do trzeciej kategorii zaliczyć należy sprawy zarówno cywilne, jak i karne podmiotów cieszących się przywilejem sądu kościelnego ${ }^{23}$. Chodzi tu o duchownych (o których w can. 120), zakonników (o których w can. 614) oraz członków stowarzyszeń pobożnych podejmujących wspólnotowe życie bez ślubów zakonnych (o których w can. 680).

${ }^{20}$ Por. Ch. Augustine, A Commentary on the New Code of Canon Law, Vol. 7, Book IV, Ecclesiastical Procedure (Can. 1552-2194), Toronto 1921, s. 5-6.

${ }^{21}$ Can. $1553 \$ 12^{\circ}$ : „Ecclesia iure proprio et exclusivo cognoscit: De violatione legum ecclesiasticarum deque omnibus in quibus inest ratio peccati, quod attinet ad culpae definitionem et poenarum ecclesiasticarum irrogationem".

${ }^{22}$ Por. F. Bączkowicz, Prawo kanoniczne, dz. cyt., s. 22-23.

${ }^{23}$ Can. $1553 \$ 13^{\circ}$ : „Ecclesia iure proprio et exclusivo cognoscit: De omnibus causis sive contentiosis sive criminalibus quae respiciunt personas privilegio fori gaudentes ad normam can. $120,614,680 "$. 


\section{Kompetencje sędziego głównego - przewodniczącego kolegium sędziowskiego}

Analiza poszczególnych dyspozycji ustawodawcy zawartych w CIC 1917 i PME pozwala wyprowadzić następujące kompetencje ${ }^{24}$ sędziego głównego - przewodniczącego kolegium sędziowskiego ${ }^{25}$ :

- podpisuje wszystkie akta sprawy (can. $1643 \$ 2)$;

- zwołuje sesję sędziowską, ilekroć: przyjmuje lub odrzuca się skargę powodową (can. 1709; art. 64); powołuje się promotora sprawiedliwości

${ }^{24}$ Pojęcie kompetencji jest wieloznaczne. Zdaniem Mirosława Sitarza przez kompetencję rozumie się najczęściej upoważnienie przyznane podmiotowi do tworzenia uprawnień lub obowiązków na rzecz innych podmiotów. Kompetencje wyznaczane są przez normy kompetencyjne, które w prawie kanonicznym wyprowadza się z prawa Bożego i prawa czysto kościelnego (por. M. Sitarz, Kompetencje organów kolegialnych $w$ Kościele partykularnym w sprawowaniu władzy wykonawczej według Kodeksu Prawa Kanonicznego z 1983 roku, Lublin 2008, s. 103; M. Sitarz, Kompetencje reprezentacyjne organów kolegialnych w Kościele partykularnym wedtug Kodeksu Prawa Kanonicznego z 1983 r., w: Historia magistra vitae. Księga jubileuszowa ku czci profesora Jerzego Flagi, red. A. Dębiński i in., Lublin 2007, s. 301). Czynniki kształtujące zakres kompetencji Józef Krukowski kwalifikuje do 3 kategorii: terytorialne, personalne i rzeczowe (por. J. Krukowski, Prawo administracyjne w Kościele, Warszawa 2011, s. 67-68). Anna Ravà podaje natomiast 4 kryteria kompetencji: przedmiotowe (oggettivo), podmiotowe (soggettivo), terytorialne (territoriale) i funkcjonalne (funzionale) (por. A. Ravà, Competenza nel diritto canonico, w: Enciclopedia del diritto, Vol. viII, a cura di D. Marchetti, G. Crisci, F. Piga, Milano 1961, s. 109-110). Więcej analiz pojęcia kompetencji por. P. Lewandowski, Kompetencje biskupa diecezjalnego dotyczące środków społecznego przekazu w Kodeksie Prawa Kanonicznego $z 1983$ roku i polskim pokodeksowym ustawodawstwie partykularnym, Tarnów 2015, s. 12-16; P. Lewandowski, Kompetencje biskupa diecezjalnego dotyczace sądownictwa kościelnego w przedmiocie procesów małżeńskich według kodeksu prawa kanonicznego $z 1983$ roku i instrukcji procesowej „Dignitas connubii”, w: Kościół lokalny w Kościele Chrystusa, red. R. Kantor, Kraków 2015, s. 110-112.

${ }^{25}$ Zgodnie z can. $1577 \$ 2$ i art. $14 \$ 2$ do pełnienia funkcji sędziego głównego w kolegium sędziowskim uprawnieni są oficjał i wiceoficjał. Więcej na temat ich kompetencji por. M. Pastuszko, Oficjat $i$ wiceoficjat $w$ procesie o nieważność matżeństwa, „Prawo Kanoniczne. Kwartalnik prawno-historyczny” 21 (1978) nr 1-2, s. 293-296. Znakomity kanonista i jeden z najlepszych znawców procedury sądowej pod rządami cic 1917 oraz PME, Francesco Roberti, kompetencje przysługujące przewodniczącemu kolegium sędziowskiego sprowadza do dwóch: „praeses collegii habet directionem totius processus” oraz „debet processum moderari” (por. F. Roberti, De processibus, Vol. 1, De actione, de praesuppositis processus et sententiae de merito, Romae 1941, s. 283). Analiza kompetencji sędziego głównego w kolegium sędziowskim za: W. Padacz, Z praktyki sądowej. Sędzia instruktor w procesie o nieważność matżeństwa, „Prawo Kanoniczne. Kwartalnik prawno-historyczny” 7 (1964) nr 3-4, s. 473-475. 
(art. $16 \$ 1$ ); odmawia się przyjęcia dalszych wniosków w procesie ze strony obrońcy (can. $19693^{\circ}-4^{\circ}$ ); dopuszcza się nowe dowody po zamknięciu przewodu sądowego (can. $1861 \$ 2$ ); decyduje się o sprawach wpadkowych (can. 1839); wydaje się decyzję dilata et compleantur acta (can. 1783; art. $201 \$ 1$ ); wydaje i podpisuje się wyrok (can. 1870; art. 198 $\$ 2$ ); odkłada się termin publikacji wyroku (art. 199); decyduje się o prowadzeniu sprawy na prawie ubogich $(\operatorname{art.} 237 \$ 1)^{26}$; istnieje konieczność zaniechania prowadzenia sprawy i złożenia akt do archiwum sądowego, o ile kolegium sędziowskie zarezerwowało sobie tę decyzję $(\operatorname{art.} 68 \$ 2)^{27}$;

- wyznacza termin zebrania kolegium sędziowskiego (can. $1871 \$ 1$; art. 185) i kieruje dyskusją w czasie jego trwania (can. $1871 \$ 3$; art. $68 \$ 1$ );

- dokonuje zawiązania sporu (art. 88) i zatwierdza jego formułę $(\text { art. } 92 \$ 1)^{28}$;

- rozpatruje słuszność ekscepcji skierowanej przeciw sędziemu, obrońcy węzła małżeńskiego lub promotorowi sprawiedliwości (can. $1614 \$ 3$ );

- wyznacza biegłych i ich liczbę (art. $68 \$ 2,141$ ) oraz określa ich honorarium (art. $\left.2342^{\circ}\right)$;

- ogłasza stronę pozwaną za oporną prawu (art. 89\$2);

- nakazuje dostarczyć dokumenty (art. $68 \$ 2$ ); decyduje o dopuszczeniu trudnych do osiągnięcia dowodów (art. $95 \$ 2$ ) oraz o terminie ich dostarczenia (art. $68 \$ 2$ ); odrzuca dekretem pisma stron lub zgłaszane dowody zmierzające do przedłużenia przewodu sądowego (art. $95 \$ 1)^{29}$; - zarządza publikację akt sprawy (art. 175\$2) i określa czas jej trwania $(\operatorname{art} .175 \$ 3)^{30}$;

${ }^{26} \mathrm{~W}$ przypadku prośby o przyznanie prawa ubogich lub zmniejszenie należnych opłat sądowych przewodniczący kolegium sędziowskiego prosi o opinię w tej sprawie obrońcę węzła małżeńskiego i promotora sprawiedliwości (art. $238 \$ 2$ ).

${ }^{27}$ W sytuacji, gdy kolegium sędziowskie nie zastrzegło sobie tej kompetencji, sędzia główny jest uprawniony do samodzielnej decyzji w tym zakresie, jednak po uprzednim zasięgnięciu opinii obrońcy węzła małżeńskiego, względnie promotora sprawiedliwości.

${ }^{28}$ Jeśli sędzia audytor jest jednym z członków kolegium sędziowskiego, wówczas jego obowiązkiem, nie zaś przewodniczącego, jest dokonać zawiązania sporu.

${ }^{29}$ Por. T. Pawluk, Ocena sędziowska środków dowodowych w procesie kanonicznym, „Prawo Kanoniczne. Kwartalnik prawno-historyczny” 12 (1969) nr 1-2, s. 147-160.

${ }^{30}$ Przed publikacją do przejrzenia akt sprawy zobligowani są: przewodniczący kolegium sędziowskiego, audytor i obrońca węzła małżeńskiego. Dostrzeżone braki proceduralne powinny zostać usunięte przed publikacją akt. 
- w wyjątkowych sytuacjach zarządza uzupełnienie akt sprawy (art. 135 $\$ 1)$;

- zarządza zamknięcie procesu sądowego (art. 176-177); po jego zamknięciu może zezwolić na uzupełnienie akt sprawy na wniosek stron lub obrońcy węzła małżeńskiego (art. $178 \$ 2)^{31}$;

- wyznacza termin składania: głosów obrończych - stronom i promotorowi sprawiedliwości (art. 179) - oraz uwag - obrońcy węzła małżeńskiego (art. $180 \$ 1$ ), zaś w razie konieczności przedłuża te terminy (art. 181);

- reguluje zbyt obszerne wywody obrońcy węzła małżeńskiego (can. 1864);

- notyfikuje ordynariuszowi miejsca, gdzie małżeństwo było zawarte, o 2 wyrokach pozytywnych (art. 224).

Przedstawione powyżej kompetencje przewodniczącego kolegium sędziowskiego nie posiadają charakteru taksatywnego. Mają istotne znaczenie dla sprawnego przeprowadzenia procesu sądowego bez niepotrzebnego przedłużania postępowania. Przyczyniają się także do tego, aby wyrok sądowy zapadł po dokładnym przygotowaniu na podstawie zeznań i dokumentów, w zgodzie z sumieniem sędziów orzekających ważność lub nieważność sakramentu ${ }^{32}$.

\section{Kompetencje sędziów pomocniczych}

Sędziami pomocniczymi są: audytor, zwany instruktorem, oraz relator, zwany ponensem.

\section{I. Audytor (instruktor)}

Ustawodawca w CIC 1917 sprecyzował jedynie niektóre kompetencje sędziego audytora (instruktora) ${ }^{33}$. Przede wszystkim gromadzi on wszelkie

${ }^{31}$ Jeśli sędzia główny w kolegium sędziowskim odmówi możliwości uzupełnienia akt sprawy, stronom lub obrońcy węzła małżeńskiego przysługuje odwołanie do całego kolegium sędziowskiego.

${ }^{32}$ Por. W. Padacz, Z praktyki sądowej. Prawa i obowiązki kolegium sądzącego, „Prawo Kanoniczne. Kwartalnik prawno-historyczny" 9 (1966) nr 3-4, s. 475.

${ }^{33}$ Sędzia audytor (instruktor) jest osobą urzędową, powoływaną fakultatywnie przez ordynariusza lub sędziego głównego, o ile to tylko możliwe spośród sędziów synodalnych. 
materiały dowodowe w zleconej mu do instrukcji sprawie pozostającej pod kierownictwem sędziego głównego w kolegium sędziowskim. Oprócz tego do audytora należy wzywanie świadków na zeznania (can. 1582, 1715), przesłuchiwanie ich (can. 1582, 1773), badanie sądowe miejsca lub przedmiotu (can. 1807), porównywanie odpisów z oryginałami dokumentów $(\text { can. } 1821 \$ 2)^{34}$.

Kompetencje przyznane sędziemu instruktorowi przez ustawodawcę kodeksowego nie wyczerpują długiej listy czynności prawnych, które wypełnia on podczas trwania procesu sądowego. Analiza poszczególnych dyspozycji zawartych w PME pozwala wyprowadzić kolejne kompetencje audytora ${ }^{35}$ :

- przed rozpoczęciem zeznań przyjmuje od stron, świadków i biegłych przysięgę na Ewangelię, że będą zeznawać tylko szczerą prawdę (art. $96 \$ 1$ ), zaś po ich zakończeniu ponownie odbiera przysięgę, że wszystko, co zostało zeznane, odpowiada prawdzie i będzie zachowane $\mathrm{w}$ tajemnicy przynajmniej do chwili publikacji akt procesu (art. 104\$2);

- stwierdza tożsamość zeznających przed sądem (art. 97);

- odbiera zeznania na podstawie pytań otrzymanych od obrońcy węzła małżeńskiego w zamkniętej kopercie bezpośrednio przed badaniem sądowym (art. 101) ${ }^{36}$; w sytuacji zgodnego twierdzenia stron, że małżeństwo uznają za nieważne, ostrożnie wyjaśnia powody, którymi kierują się

Urzędu tego nie może wypełniać wierny świecki (por. T. Pieronek, Normy ogólne..., dz. cyt., s. 120). CIC 1917 stosuje 2 nazwy dla określenia analizowanego urzędu: audytor (auditor) i instruktor procesu (instructor actorum). Użycie w can. 1580 $\$ 1$ spójnika seu („Potest Ordinarius unum aut plures auditores, seu actorum instructores sive stabiliter sive pro certa aliqua causa constituere" [pogrubienie - P. L.]) oraz hasła zamieszczone w indeksie analityczno-alfabetycznym CIC 1917 (auditores i instructores vide auditores) wskazują na to, że nazwy te dotyczą tego samego sędziego i mogą być stosowane zamiennie. Warto nadmienić, że Codex Iuris Canonici z 1983 nie podtrzymuje podwójnego nazewnictwa na oznaczenie urzędu sędziego instruktora, zachowując jedynie nazwę audytor (auditor). Nazwę instruktor (instructor) rezerwuje natomiast dla prowadzącego na zlecenie biskupa diecezjalnego instrukcję procesu o dyspensę od małżeństwa zawartego, a niedopełnionego (por. S. Bista, Kompetencje sędziego instruktora $w$ procesie matżeńskim, „Roczniki Teologiczno-Kanoniczne" 33 (1986) z. 5, s. 6).

${ }^{34}$ Por. F. Bączkowicz, Prawo kanoniczne, dz. cyt., s. 30.

${ }^{35}$ Analiza kompetencji sędziego audytora (instruktora) za: W. Padacz, Z praktyki sądowej. Sędzia instruktor..., dz. cyt., s. 219-225.

${ }^{36}$ Sędzia audytor po zawiązaniu sporu przesłuchuje najpierw stronę powodową, później zaś pozwaną. 
małżonkowie, potwierdzając tezę powodową (art. $113 \$ 2$ ); jeżeli na podstawie zeznań stron wyłoni się podejrzenie, że małżonkowie uzgodnili między sobą treść wypowiedzi, zadaje szereg pytań ex officio (art. $113 \$ 3$ ); gdy zaś zeznania stron różnią się od siebie w zasadniczych punktach, w porozumieniu z obrońcą węzła małżeńskiego wyjaśnia zachodzące sprzeczności, doprowadzając nawet do konfrontacji stron (can. 1772; art. 114\$2, 133);

- wzywa świadków z urzędu dla właściwego poznania szczegółów i okoliczności zachodzących w prowadzonej sprawie lub dla uzupełnienia instrukcji dowodowej (art. $123 \$ 1)$;

- decyduje o liczbie świadków dopuszczonych przed trybunał (art. 123 $\$ 2,124)^{37}$;

- po złożeniu zeznań poleca notariuszowi odczytać protokół stronie, świadkowi i biegłemu, w razie potrzeby nanosi stosowne poprawki, i gdy upewni się, że wszystko zostało dokładnie wyrażone i zanotowane, podpisuje zeznania (art. 104);

- wyznacza tłumacza, po zasięgnięciu opinii stron i obrońcy węzła małżeńskiego (art. 108);

- przed publikacją akt analizuje zgromadzony materiał dowodowy ${ }^{38}$, gdy zaś dojdzie do przekonania, że w prowadzonej sprawie nadal istnieją niejasności, które dadzą się usunąć, ma prawo wezwać nowych świadków lub zażądać nowych dokumentów (art. 134);

- poza przypadkami określonymi w CIC $1917^{39}$ powołuje odpowiednich biegłych (art. 140); w dekrecie formułuje wątpliwości, na które w określonym czasie mają odpowiedzieć ( $\operatorname{art.} 147 \$ 1,4)$; decyduje również, czy całość akt czy tylko niektóre ich części należy przekazać biegłym (art. $147 \$ 2$ ), czy pytania stron przygotowane dla biegłych przyjąć czy odrzucić $(\operatorname{art.} 147 \$ 3)^{40}$;

- na wniosek stron nadaje bieg sprawom wpadkowym (art. 188) ${ }^{41}$.

${ }^{37}$ Co do zasady świadkowie są przesłuchiwani bez obecności stron, ich zastępców czy adwokatów. W uzasadnionych okolicznościach sędzia instruktor może zezwolić na asystencję strony powodowej lub pozwanej, względnie ich zastępców prawnych (art. 128).

$3^{38}$ Oprócz sędziego audytora podobnie czyni obrońca węzła małżeńskiego.

39 Por. can. 1976-1982.

${ }^{40} \mathrm{~W}$ sprawach prowadzonych $\mathrm{z}$ tytułów choroby umysłowej lub impotencji po przekazaniu pisemnej opinii sędzia instruktor wzywa biegłego do siedziby trybunału w celu dodatkowego złożenia ustnych zeznań pod przysięgą (art. 152).

${ }^{41}$ Jeśli sędzia audytor odmówi podjęcia sprawy wpadkowej, strony mają prawo w ciągu 10 dni odwołać się od tej decyzji do kolegium sędziowskiego (art. 188). 


\subsection{Relator (ponens)}

Zgodnie z dyspozycją ustawodawcy kodeksowego zawartą w can. 1584 sędzia przewodniczący trybunału kolegialnego obligatoryjnie wyznacza jednego spośród sędziów kolegium jako relatora (ponensa) ${ }^{42}$.

Sędziemu relatorowi przysługują 2 kompetencje: referowanie sprawy wobec pozostałych członków trybunału kolegialnego i redagowanie na piśmie wyroku.

Pierwsze zadanie ponens wykonuje $\mathrm{w}$ ten sposób, że przygotowaną przez audytora sprawę do wyrokowania studiuje, a następnie redaguje na piśmie opinię i jako pierwszy czyta swój wniosek umotywowany in iure et in facto na sesji trybunału, podczas którego ma być podjęty wyrok ${ }^{43}$.

Drugie zadanie relator wypełnia po podjęciu przez trybunał kolegialny decyzji będącej albo wyrokiem ostatecznym, albo dekretem, redagując ją na piśmie zgodnie z przepisami prawa, wykorzystując $\mathrm{w}$ tej pracy wszystkie wnioski kolegium sędziowskiego - według swojego uznania lub kierując się wskazaniami sędziów, o ile zdecydowali, jakich motywów in iure et in facto należy użyć w ostatecznej redakcji decyzji ${ }^{44}$.

${ }^{42}$ Kanoniści nie są zgodni co do tego, czy przewodniczący kolegium sędziowskiego może wyznaczyć samego siebie na relatora. Matthaeus Conte a Coronata (Institutiones Iuris Canonici. Ad usum utriusque cleri et scholarum, Vol. 3, De processibus, ed. 3 aucta et emendata, Torino 1948, s. 34) i Iosepho Noval (Commentarium Codicis Iuris Canonici, Vol. 1, De processibus, Romae 1920, s. 75) opowiadają się za tym, aby rolę ponensa odgrywał sędzia trybunału, który nie jest przewodniczącym. Inni, jak Francisco Xavier Wernz i Petri Vidal (Ius Canonicum, Vol. 6, De processibus, Romae 1927, s. 91) czy Guidus Cocchi (Commentarium in Codicem Iuris Canonici. Ad usum scholarum, Lib. 4, De processibus, ed. 2, Torino 1936, s. 52), uważają, że sędzia główny w kolegium sędziowskim może wyznaczyć samego siebie na relatora (chociaż niektórzy z nich, powołując się na dyspozycję zawartą $\mathrm{w}$ art. $22 \$ 1 \mathrm{PME}$, wymagają do tego zgody członków kolegium). Por. także: M. Pastuszko, $Z$ praktyki sądowej. Sędzia ponens w kanonicznym procesie o nieważność małżeństwa, „Prawo Kanoniczne. Kwartalnik prawno-historyczny" 19 (1976) nr 3-4, s. 339-341.

${ }^{43}$ Can. $1871 \$ 3$ : „Prolatis ex ordine, secundum praecedentiam, ita tamen ut semper a causae ponente seu relatore initium fiat, singulorum conclusionibus, habeatur moderata discussio sub tribunalis praesidis ductu, praesertim ut constabiliatur quid statuendum sit in parte dispositiva sententiae".

${ }^{44}$ Por. T. Pieronek, Normy ogólne..., dz. cyt., s. 126. 


\section{Sędziowie pierwszej instancji Sądu Diecezjalnego w Tarnowie w latach 1945-1983}

W latach 1945-1983 w procesach prowadzonych w pierwszej instancji Sądu Diecezjalnego w Tarnowie orzekało 38 sędziów:

Ksiądz Stanisław Adamczyk - urodzony 11 października 1900 roku w Łękach koło Szczepanowa, syn Stanisława Adamczyka i Magdaleny Rogóż. Święcenia kapłańskie przyjął 29 czerwca 1923 roku z rąk biskupa Leona Wałęgi. Doktorat z filozofii uzyskał 9 lipca 1928 roku na Papieskim Uniwersytecie Gregoriańskim. Habilitował się w 1939 roku na Uniwersytecie Jana Kazimierza we Lwowie. Wykładowca Instytutu Teologicznego w Krakowie i Katolickiego Uniwersytetu Lubelskiego. Czynny członek Towarzystwa Naukowego KUL-u. Szambelan papieski i prałat domowy ojca świętego. Sędzia prosynodalny (mianowany 24 listopada 1952 roku) i wiceoficjał Sądu Diecezjalnego w Tarnowie. Zmarł 3 stycznia 1971 roku ${ }^{45}$.

Biskup Piotr Bednarczyk - urodzony 23 lutego 1914 roku w Sowlinach koło Limanowej, syn Stanisława Bednarczyka i Barbary Jasicy. Święcenia kapłańskie przyjął 3 czerwca 1944 roku z rąk kardynała Adama Stefana Sapiehy. Doktorat z filozofii uzyskał w 1947 roku na Uniwersytecie Poznańskim, doktorat z teologii w 1952 roku na Uniwersytecie Jagiellońskim. Wicerektor Wyższego Seminarium Duchownego w Tarnowie. Wizytator diecezjalny i referent do spraw katechezy. Dnia 21 lutego 1968 roku mianowany biskupem pomocniczym diecezji tarnowskiej ze stolicą tytularną Turris Rotunda. Święcenia biskupie przyjął 21 kwietnia 1968 roku z rąk kardynała Karola Wojtyły, arcybiskupa Jerzego Ablewicza i biskupa Karola Pękali. Sędzia prosynodalny Sądu Diecezjalnego w Tarnowie - mianowany 18 lutego 1954 roku. Zmarł 7 sierpnia 2001 roku$^{46}$.

${ }^{45}$ Por. Ks. Stanisław Adamczyk, Archiwum Diecezjalne w Tarnowie [dalej: ADT], PA II/1; Najwyższe władze diecezjalne. Kuria diecezjalna. Nominacje sędziów i urzędników sądowych, ADT, ARZ 193/1; Adamczyk Stanisław (1900-1971), w: A. Nowak, Słownik biograficzny kapłanów diecezji tarnowskiej 1786-1985, t. 2, Tarnów 2000, s. 9-10; S. Kowalczyk, Adamczyk Stanisław ks., w: Encyklopedia katolicka, t. 1, red. F. Gryglewicz, R. Łukaszyk, Z. Sułowski, Lublin 1995, kol. 74; Ks. Prałat Dr Stanisław Adamczyk (1900-1971), w: J. Rzepa, Rzut oka na przeszłość, Tarnów 1982, s. 55. W przypisach do artykułu pozostawiono oryginalny sposób zapisu tytułów prac, do których się odwoływano.

${ }^{46}$ Por. M. Czosnyka, Piotr Bednarczyk (1914-2001) - tarnowski biskup pomocniczy 19681991, http://www.mmtarnow.com/2012/o9/piotr-bednarczyk-1914-2001-tarnowski.html 
Paweł Lewandowski

Ksiądz Michał Bednarz - urodzony 26 września 1939 roku w Skrzyszowie. Święcenia kapłańskie przyjął 29 czerwca 1963 roku z rąk arcybiskupa Jerzego Ablewicza. Licencjat nauk teologicznych w zakresie biblistyki uzyskał na Katolickim Uniwersytecie Lubelskim. Licencjat nauk biblijnych uzyskał w Papieskim Instytucie Biblijnym w Rzymie. Doktorat z teologii w zakresie teologii biblijnej uzyskał w 1971 roku na Papieskim Uniwersytecie Świętego Tomasza z Akwinu (Angelicum). Absolwent École Biblique et Archéologique Française de Jérusalem. Habilitował się w 2001 roku na Papieskiej Akademii Teologicznej w Krakowie. Długoletni wykładowca Pisma Świętego na Wydziale Teologicznym Sekcja w Tarnowie Uniwersytetu Papieskiego Jana Pawła II w Krakowie, w Wyższym Seminarium Duchownym w Rzeszowie i w Gródku Podolskim na Ukrainie. Kapelan Jego Świątobliwości. Sędzia prosynodalny Sądu Diecezjalnego w Tarnowie - mianowany 25 maja 1977 roku $^{47}$.

Ksiądz Jan Białobok - urodzony 15 lipca 1927 roku w Szymbarku. Święcenia kapłańskie przyjął 4 maja 1952 roku z rąk biskupa Jana Stepy. Doktorat z prawa kanonicznego uzyskał w 1960 roku na Katolickim Uniwersytecie Lubelskim. Kierownik Archiwum Diecezjalnego w Tarnowie. Proboszcz w Lisiej Górze i Mielcu. Dziekan dekanatu mieleckiego. Kapelan Jego Świątobliwości. Obrońca węzła małżeńskiego, sędzia prosynodalny (mianowany 13 marca 1973 roku) i rzecznik sprawiedliwości Sądu Diecezjalnego w Tarnowie. Oficjał Sądu Diecezjalnego w Rzeszowie (1997-2003). Zmarł 2 czerwca 2007 roku $^{48}$.

Ksiądz Tadeusz Brzegowy - urodzony 20 lutego 1941 roku. Święcenia kapłańskie przyjął 27 czerwca 1965 z rąk arcybiskupa Jerzego Ablewicza. Absolwent Katolickiego Uniwersytetu Lubelskiego, Papieskiego Instytutu Biblijnego w Rzymie, Papieskiego Uniwersytetu Gregoriańskiego

(27.09.2018); Najwyższe władze diecezjalne. Kuria..., dz. cyt.; Rocznik diecezji tarnowskiej na rok 1959, Tarnów 1959, s. 26; Rocznik diecezji tarnowskiej na rok 1963, Tarnów 1963, s. 28; Rocznik diecezji tarnowskiej na rok 1967, Tarnów 1967, s. 67.

${ }^{47}$ Por. Najwyższe władze diecezjalne. Kuria..., dz. cyt.; M. Bednarz, Ewangelie synoptyczne, Tarnów 2003, nota o autorze; Michał Bednarz, https://pl.wikipedia.org/wiki/ Micha\%C5\%82_Bednarz (22.08.2017).

${ }^{48}$ Por. Najwyższe władze diecezjalne. Kuria..., dz. cyt.; Schematyzm diecezji tarnowskiej na rok 1977, Tarnów 1977, s. 69; Schematyzm diecezji tarnowskiej 1983, Tarnów 1983, s. 50; A. Nita, Zmarł ks. prałat Jan Białobok - emerytowany oficjał Sądu Biskupiego w Rzeszowie, http://www2.diecezja.rzeszow.pl/?q=node/1235 (5.07.2017). 
(doktorat w 1975 roku), École Biblique et Archéologique Française de Jérusalem oraz Catholic University of America. Habilitował się w 1989 roku na Katolickim Uniwersytecie Lubelskim. Od 1998 roku profesor nauk teologicznych. Prefekt Wyższego Seminarium Duchownego w Tarnowie. Długoletni wykładowca Papieskiej Akademii Teologicznej w Krakowie i Tarnowie. Sędzia prosynodalny Sądu Diecezjalnego w Tarnowie - mianowany 25 maja 1977 roku $^{49}$.

Ksiądz Józef Brudz - urodzony 15 listopada 1912 roku w Weryni koło Kolbuszowej, syn Michała Brudza i Zofii Czach. Święcenia kapłańskie przyjął 11 sierpnia 1935 roku w Tuchowie z rąk biskupa Edwarda Komara. Doktorat z teologii uzyskał w 1937 roku na Uniwersytecie Leopolda i Franciszka w Innsbrucku. Habilitował się na Uniwersytecie Jagiellońskim w Krakowie. Aresztowany przez Gestapo 24 maja 1941 roku. Więzień obozów koncentracyjnych w Oświęcimiu, Brzezince, Gross-Rosen i Dachau. Wykładowca dogmatyki w Instytucie Teologicznym w Tarnowie, Instytucie Teologicznym Księży Sercanów w Stadnikach i na Papieskim Wydziale Teologicznym w Krakowie. Prałat domowy ojca świętego. Sędzia prosynodalny Sądu Diecezjalnego w Tarnowie. Zmarł 14 września 1985 roku $^{50}$.

Ksiądz Stanisław Bulanda - urodzony 28 marca 1887 roku w Czchowie, syn Jana Bulandy i Anny Misiewicz. Święcenia kapłańskie przyjął 29 czerwca 1909 roku z rąk biskupa Leona Wałęgi. Doktorat z prawa kanonicznego uzyskał 27 czerwca 1912 roku na Uniwersytecie Świętego Apolinarego w Rzymie. Odbył roczny kurs procedury sądowej w Rocie Rzymskiej. Wykładowca prawa kanonicznego, historii sztuki i socjologii w Wyższym Seminarium Duchownym w Tarnowie. Notariusz i kanclerz Kurii Diecezjalnej w Tarnowie. Wikariusz kapitulny i wikariusz generalny diecezji tarnowskiej. Promotor III Synodu Diecezjalnego w Tarnowie. Szambelan papieski i prałat domowy ojca świętego. Długoletni pracownik

49 Por. Najwyższe władze diecezjalne. Kuria..., dz. cyt.; Schematyzm diecezji tarnowskiej 1983, dz. cyt., s. 50; T. Brzegowy, Pięcioksiag Mojzesza. Wprowadzenie i egzegeza Księgi Rodzaju 1-11, wyd. 4 zm. i poszerz., Tarnów 2002, nota o autorze; Tadeusz Brzegowy, https:// pl.wikipedia.org/wiki/Tadeusz_Brzegowy (22.08.2017).

${ }^{50}$ Por. Ks. Józef Brudz, ADT, PB xI/5; Brudz Józef (1912-1985), w: A. Nowak, Stownik biograficzny..., dz. cyt., t. 2, s. 90-91; J. Dudziak, Śp. Ks. Józef Brudz, „Currenda” 136 (1986), s. 300-310; Rocznik diecezji tarnowskiej na rok 1963, dz. cyt., s. 28; Rocznik diecezji tarnowskiej na rok 1967, dz. cyt., s. 67; Rocznik diecezji tarnowskiej na rok 1972, Tarnów 1972, s. 46. 
Sądu Diecezjalnego w Tarnowie - obrońca węzła małżeńskiego, sędzia, wiceoficjał i oficjał. Zmarł 5 kwietnia 1949 roku $^{51}$.

Ksiądz Walenty Chrobak - urodzony 14 stycznia 1889 roku w Bochni, syn Walentego Chrobaka i Katarzyny Młodkowskiej (Młotkowskiej). Święcenia kapłańskie przyjął 29 czerwca 1912 roku z rąk biskupa Leona Wałęgi. Referent Kurii Diecezjalnej do spraw katechetycznych i diecezjalny wizytator nauki religii. Szambelan papieski i prałat domowy ojca świętego. Sędzia prosynodalny Sądu Diecezjalnego w Tarnowie. Zmarł 26 kwietnia 1962 roku $^{52}$.

Ksiądz Ludwik Curyło - urodzony 21 października 1908 roku w Kupieninie, syn Jana Curyły i Anny Król. Święcenia kapłańskie przyjął 29 czerwca 1934 roku z rąk biskupa Franciszka Lisowskiego. Doktorat z teologii uzyskał 30 czerwca 1949 roku na Uniwersytecie Jagiellońskim. Dziekan dekanatu tuchowskiego i kolbuszowskiego. Sędzia prosynodalny Sądu Diecezjalnego w Tarnowie - mianowany 24 listopada 1951 roku. Zmarł 22 czerwca 1987 roku $^{53}$.

Ksiądz Stefan Czerw - urodzony 28 lipca 1892 roku w Chorzelowie, syn Marcina Czerwa i Anny Kurdziel. Święcenia kapłańskie przyjął 24 czerwca 1917 roku z rąk biskupa Leona Wałęgi. Wikariusz w Grybowie i Tarnowie. Katecheta w Starym Sączu, Brzesku, Tarnowie i Nowym Sączu. Cenzor ksiąg religijnych. Sędzia prosynodalny Sądu Diecezjalnego w Tarnowie mianowany 24 listopada 1951 roku. Zmarł 8 maja 1978 roku $^{54}$.

${ }^{51}$ Por. Ks. Stanisław Bulanda, ADT, PB XI/15; J. Białobok, Bulanda Stanisław (1887-1949), w: Najwyższe władze diecezjalne. Kuria..., dz. cyt.; J. Rzepa, Ks. prałat dr Stanisław Bulanda (1887-1949), „Currenda” 132 (1982), s. 134-136; P. Stach, Życie i działalność śp. ks. dra Stanisława Bulandy, „Currenda” 111 (1961), s. 227-244; Bulanda Stanistaw (1887-1949), w: A. Nowak, Słownik biograficzny kapłanów diecezji tarnowskiej 1786-1985, t. 1, Tarnów 1999, s. 87-89; W. Szczebak, Trzej pionierzy tarnowskiej muzyki kościelnej, „Currenda” 138 (1988), s. 218220; R. Banach, Bulanda Stanisław ks., w: Encyklopedia katolicka, t. 2, red. F. Gryglewicz, R. Łukaszyk, Z. Sułowski, Lublin 1976, kol. 1190; J. Pajor, Szlachetna działalność ks. dr. Stanisława Bulandy $w$ diecezji tarnowskiej, w: Ks. Stanisław Bulanda, ADT, PB XI/15.

${ }_{52}$ Por. Ks. Walenty Chrobak, ADT, PC IV/15; Ks. Prałat Walenty Chrobak (1889-1962), w: J. Rzepa, Rzut oka..., dz. cyt., s. 48-50; P. Bednarczyk, Myśli, w: Ks. Walenty Chrobak, ADT, PC IV/15; Chrobak Walenty (1889-1962), w: A. Nowak, Słownik biograficzny..., dz. cyt., t. 2, s. 91-92.

${ }^{53}$ Por. Ks. Ludwik Curyło, ADT, PC vi/7; Najwyższe władze diecezjalne. Kuria..., dz. cyt.; Rocznik diecezji tarnowskiej na rok 1959, dz. cyt., s. 26; Rocznik diecezji tarnowskiej na rok 1963, dz. cyt., s. 28; Rocznik diecezji tarnowskiej na rok 1967, dz. cyt., s. 67.

${ }^{54}$ Por. Ks. Stefan Czerw, ADT, PC vi/14; Najwyższe władze diecezjalne. Kuria..., dz. cyt.; Wspomnienie o śp. Ks. Prof. Stefanie Czerwie (1892-1978), w: Ks. Stefan Czerw, ADT, dz. cyt.; 
Ksiądz Ignacy Dziedziak - urodzony 24 stycznia 1904 roku w Białej Wyżnej koło Grybowa, syn Wawrzyńca Dziedziaka i Wiktorii Góry. Święcenia kapłańskie przyjął 29 czerwca 1928 roku z rąk biskupa Leona Wałęgi. Doktorat z teologii (31 października 1931 roku) i z prawa kanonicznego (16 lipca 1934 roku) uzyskał na Papieskim Uniwersytecie Gregoriańskim. Wykładowca prawa kanonicznego, katolickiej nauki społecznej i języka łacińskiego w Wyższym Seminarium Duchownym w Tarnowie. Zastępca promotora III Synodu Diecezji Tarnowskiej. Kanclerz Kurii Diecezjalnej w Tarnowie. Szambelan papieski. Obrońca węzła małżeńskiego, wiceoficjał i oficjał Sądu Diecezjalnego w Tarnowie. Zmarł 15 stycznia 1968 roku $^{55}$.

Ksiądz Karol Dziubaczka - urodzony 7 października 1944 roku. Święcenia kapłańskie przyjął 25 maja 1969 roku z rąk arcybiskupa Jerzego Ablewicza. Doktorat z prawa kanonicznego uzyskał w 1979 roku na Katolickim Uniwersytecie Lubelskim. Kanonik gremialny Kapituły Katedralnej w Tarnowie. Kapelan Jego Świątobliwości. Sędzia Sądu Diecezjalnego w Tarnowie - iuram. 27 września 1979 roku $^{56}$.

Ksiądz Piotr Mieczysław Gajda - urodzony 8 lutego 1927 roku w Porąbce Uszewskiej, syn Andrzeja i Stefanii. Święcenia kapłańskie przyjął 29 kwietnia 1951 roku z rąk biskupa Jana Stepy. Doktorat z prawa kanonicznego uzyskał w 1955 roku na Katolickim Uniwersytecie Lubelskim. Kapelan i sekretarz biskupa Jana Stepy. Notariusz Kurii Diecezjalnej w Tarnowie. Długoletni wykładowca liturgiki i homiletyki w Wyższym Seminarium Duchownym w Tarnowie i Rzeszowie. Długoletni pracownik

Czerw Stefan (1892-1978), w: A. Nowak, Stownik biograficzny..., dz. cyt., t. 2, s. 139; E. Krężel, Śp. Ks. Stefan Czerw, „Currenda” 128 (1978), s. 232-266; Ks. Profesor Stefan Czerw (1892-1978), w: J. Rzepa, Rzut oka..., dz. cyt., s. 67-68.

55 Por. Ks. Ignacy Dziedziak, ADT, PC VII/3; K. Talarek, Ks. Ignacy Dziedziak, w: Ks Ignacy Dziedziak, ADT, dz. cyt.; S. Pycior, Dziedziak Ignacy (1904-1968), w: Ks. Ignacy Dziedziak, ADT, dz. cyt.; Przemówienie J.E. Księdza Biskupa Ordynariusza wygłoszone w Grybowie 18.I.1968 r. na pogrzebie śp. Księdza Prałata Ignacego Dziedziaka, w: Ks. Ignacy Dziedziak, ADT, dz. cyt.; Dziedziak Ignacy (1904-1968), w: A. Nowak, Słownik biograficzny..., dz. cyt., t. 2, s. 181-182; P. Śliwa, Śp. ks. dr Ignacy Dziedziak, „Currenda” 123 (1973), s. 128-134; Ks. Prałat Dr Ignacy Dziedziak (1904-1968), w: J. Rzepa, Rzut oka..., dz. cyt., S. $52-53$.

${ }^{56}$ Por. Najwyższe władze diecezjalne. Kuria..., dz. cyt.; L. Fiejdasz, M. Pawelec, Doktoraty 1926-2010, w: Wydział Prawa, Prawa Kanonicznego i Administracji KUL. Ludzie nauka - struktura, red. L. Fiejdasz, P. Stanisz, E. Szczot, Lublin 2010, s. 180. 
Sądu Diecezjalnego w Tarnowie: oficjał - mianowany w 1973 roku - i sędzia - mianowany w 1992 roku $^{57}$. Zmarł 2 czerwca 2018 roku.

Ksiądz Wawrzyniec Gnutek - urodzony 1 sierpnia 1901 roku w Okulicach, syn Jana Gnutka i Anny Muchy. Święcenia kapłańskie przyjął 29 czerwca 1925 roku z rąk biskupa Leona Wałęgi. Licencjat z Pisma Świętego uzyskał 25 czerwca 1928 roku w Papieskim Instytucie Biblijnym w Rzymie. Wykładowca Pisma Świętego w Wyższym Seminarium Duchownym w Tarnowie. Ojciec duchowny Wyższego Seminarium Duchownego w Tarnowie i Papieskiego Kolegium Polskiego w Rzymie. Szambelan papieski. Sędzia synodalny Sądu Diecezjalnego w Tarnowie - iuram. 18 marca 1947 roku. Zmarł 29 sierpnia 1982 roku $^{58}$.

Ksiądz Olgierd Kokociński - urodzony 22 stycznia 1916 roku w Odolanowie. Do Kongregacji Oratorium Świętego Filipa Neri wstąpił w Gostyniu w 1937 roku. Święcenia kapłańskie przyjął 8 czerwca 1941 roku. Przełożony Kongregacji Oratorium Świętego Filipa Neri w Studziannie, Tarnowie i Rzymie. Wizytator kongregacji filipińskich w Polsce. Prokurator polskiej i włoskiej Federacji Kongregacji Oratorium Świętego Filipa Neri. Odznaczony orderem Pro Ecclesia et Pontifice. Sędzia prosynodalny Sądu Diecezjalnego w Tarnowie - mianowany 18 lutego 1954 roku. Zmarł 4 lipca 2001 roku $^{59}$.

Ksiądz Jan Kos - urodzony 30 marca 1917 roku w Podegrodziu, syn Jana Kosa i Marii Nowińskiej. Święcenia kapłańskie przyjął 9 sierpnia 1942 roku z rąk biskupa Edwarda Komara. Doktorat z teologii uzyskał 30 czerwca 1951 roku na Uniwersytecie Jagiellońskim. Proboszcz w Bielczy i Starym Sączu.

57 Por. A. Nowak, Gajda Piotr Mieczysław (1927), w: Najwyższe władze diecezjalne. Kuria..., dz. cyt.; L. Fiejdasz, M. Pawelec, Doktoraty 1926-2010, dz. cyt., s. 173; P. M. Gajda, Niedziela chrześcijanina, Kraków 2015, nota o autorze.

${ }_{58}^{8}$ Por. Ks. Wawrzyniec Gnutek, ADT, PG VIII/5; Najwyższe władze diecezjalne. Kuria..., dz. cyt.; P. Śliwa, Kazanie po wprowadzeniu zwłok ś.p. Ks. Prałata Wawrzyńca Gnutka $z$ domu rodzinnego do kościoła paraf. w Okulicach, dnia 1.IX.1982, w: Ks. Wawrzyniec Gnutek, ADT, dz. cyt.; S. Pycior, Dziedziak Ignacy (1904-1968), w: Ks. Ignacy Dziedziak, ADT, dz. cyt.; Przemówienie J.E. Księdza Biskupa Ordynariusza wygłoszone w Grybowie..., dz. cyt.; Gnutek Wawrzyniec (1901-1982), w: A. Nowak, Stownik biograficzny..., dz. cyt., t. 2, s. 230-231; M. Bednarz, Ks. Wawrzyniec Gnutek, „Currenda” 133 (1983), s. 222-225; A. Nowak, Gnutek Wawrzyniec (1901-1982), w: Słownik polskich teologów katolickich 1981-1993, t. 8, red. J. Mandziuk, Warszawa 1995, s. 181-182.

${ }_{59}$ Por. Najwyższe władze diecezjalne. Kuria..., dz. cyt.; Z. Starczewski, Śp. Ks. Olgierd Kokociński cor, „Świętogórska Róża Duchowna” 34 (2001) nr 4 (176), s. 8-9. 
Notariusz dekanatu starosądeckiego. Sędzia prosynodalny Sądu Diecezjalnego w Tarnowie - iuram. 21 listopada 1959 roku. Zmarł 13 lipca 1991 roku $^{60}$.

Ksiądz Kazimierz Kupiec - urodzony 1 listopada 1937 roku w Chorzelowie, syn Ludwika Kupca i Zofii Jasińskiej. Święcenia kapłańskie przyjął 29 czerwca 1961 roku z rąk biskupa Karola Pękali. W 1962 roku skierowany na studia $\mathrm{z}$ filozofii praktycznej na Katolickim Uniwersytecie Lubelskim. W 1966 roku skierowany na studia z teologii dogmatycznej i ekumenicznej na Papieskim Uniwersytecie Gregoriańskim, na którym 7 czerwca 1972 roku uzyskał doktorat z teologii. Wykładowca teologii dogmatycznej i propedeutyki teologii w Wyższym Seminarium Duchownym w Tarnowie. Sędzia prosynodalny Sądu Diecezjalnego w Tarnowie mianowany 13 marca 1973 roku. Zmarł 7 marca 1997 roku $^{61}$.

Ksiądz Władysław Lesiak - urodzony 2 kwietnia 1908 roku w Jodłowej, syn Józefa Lesiaka i Tekli Kity. Święcenia kapłańskie przyjął 29 czerwca 1930 roku z rąk biskupa Leona Wałęgi. Doktorat z teologii uzyskał na Uniwersytecie Jagiellońskim. Ojciec duchowny Wyższego Seminarium Duchownego w Tarnowie. Członek komisji a vigilantia. Radca Kurii Diecezjalnej w Tarnowie. Proboszcz w Nowym Sączu. Dziekan dekanatu Nowy Sącz-Północ. Protonotariusz apostolski. Sędzia synodalny Sądu Diecezjalnego w Tarnowie. Zmarł 9 czerwca 1977 roku $^{62}$.

Ksiądz Stanisław Łach - urodzony 7 marca 1906 roku w Gorzkowie, syn Antoniego Łacha i Marii Śmietany. Święcenia kapłańskie przyjął 29 czerwca 1930 roku z rąk biskupa Leona Wałęgi. Doktorat z teologii uzyskał 31 października 1936 roku na Uniwersytecie Jana Kazimierza we Lwowie. W 1938 roku uzyskał licencjat z Pisma Świętego w Papieskim Instytucie Biblijnym

${ }^{60}$ Por. Ks. Jan Kos, ADT, PK XIV/7; Najwyższe władze diecezjalne. Kuria..., dz. cyt.; Rocznik diecezji tarnowskiej na rok 1963, dz. cyt., s. 28; Rocznik diecezji tarnowskiej na rok 1967, dz. cyt., s. 67; Rocznik diecezji tarnowskiej na rok 1972, dz. cyt., s. 46; Schematyzm diecezji tarnowskiej na rok 1977, dz. cyt., s. 69; Schematyzm diecezji tarnowskiej 1983, dz. cyt., s. 50.

${ }^{61}$ Por. Ks. Kazimierz Kupiec, ADT, PK XvII/5; Najwyższe władze diecezjalne. Kuria..., dz. cyt.; Schematyzm diecezji tarnowskiej na rok 1977, dz. cyt., s. 69; Schematyzm diecezji tarnowskiej 1983, dz. cyt., s. 50.

${ }^{62}$ Por. Ks. Władysław Lesiak, ADT, PL Iv/5; I. Michałowicz-Hajduk, Droga do kapłaństwa... Ksiądz Infułat Władysław Lesiak (1908-1977), „Nasze Spotkania. Pismo Parafii Świętej Małgorzaty w Nowym Sączu” 164 (2008) nr 12, s. 5; Przemówienie Biskupa Józefa Gucwy wygłoszone dnia 12.VI.1977 r. podczas wprowadzenia zwłok śp. Ks. Infułata dra Władysława Lesiaka do fary nowosądeckiej, w: Ks. Władysław Lesiak, ADT, dz. cyt.; Rocznik diecezji tarnowskiej na rok 1950, Tarnów 1950, s. 26. 
w Rzymie. Sekretarz biskupa Leona Wałęgi i biskupa Franciszka Lisowskiego. Wykładowca Pisma Świętego w Wyższym Seminarium Duchownym w Tarnowie. Uzyskał tytuł docenta teologii na Uniwersytecie Jagiellońskim 1 października 1945 roku. Od 1 października 1952 roku wykładowca Katolickiego Uniwersytetu Lubelskiego. Prodziekan i dziekan Wydziału Teologii KUL-u. Dnia 10 grudnia 1956 roku uzyskał tytuł profesora nadzwyczajnego, zaś 1 października 1966 roku tytuł profesora zwyczajnego. Wypromował 24 doktorów teologii. Opublikował ponad 100 artykułów i rozpraw. Prałat honorowy ojca świętego. Obrońca węzła małżeńskiego i sędzia synodalny Sądu Diecezjalnego w Tarnowie. Zmarł 8 czerwca 1983 roku $^{63}$.

Ksiądz Franciszek Ozorka - urodzony 9 stycznia 1931 roku w Niedzieliskach, syn Jana Ozorki i Marii Czachor. Święcenia kapłańskie przyjął 29 czerwca 1955 roku z rąk biskupa Karola Pękali. Studia specjalistyczne odbył na Katolickim Uniwersytecie Lubelskim i na Papieskim Uniwersytecie Laterańskim, w którym 10 czerwca 1971 roku uzyskał doktorat z teologii. Prefekt i wykładowca teologii moralnej w Wyższym Seminarium Duchownym w Tarnowie. Referent Kurii Diecezjalnej w Tarnowie. Proboszcz w Lisiej Górze. Sędzia prosynodalny Sądu Diecezjalnego w Tarnowie - mianowany 25 maja 1977 roku. Zmarł 19 stycznia 2011 roku $^{64}$.

Ksiądz Franciszek Mróz - urodzony 6 sierpnia 1871 roku w Woli Rzędzińskiej, syn Pawła Mroza i Marii Kaczor. Święcenia kapłańskie przyjął 30 czerwca 1895 roku z rąk biskupa Ignacego Łobosa. Wikariusz w Szczucinie i Chełmie. W 1900 roku wstąpił do Kongregacji Oratorium Świętego Filipa Neri w Tarnowie, w której pełnił funkcję m.in. prepozyta. Sędzia prosynodalny Sądu Diecezjalnego w Tarnowie - mianowany 6 lutego 1924 roku. Zmarł w 1955 roku $^{65}$.

${ }^{63}$ Por. Ks. Stanisław Łach, ADT, PK II/2; M. Bednarz, Ks. Profesor Stanisław Łach - wielki biblista, „Currenda” 134 (1984), s. 231-236; S. Grzybek, Homilia wygtoszona na pogrzebie śp. Ks. Prof. Stanisława Łacha w dniu 12 czerwca 1983 r., „Ruch Biblijny i Liturgiczny” 37 (1984), s. 2-5; S. Piech, Łach Stanisław (1906-1983), w: Stownik polskich teologów..., dz. cyt., t. 8, s. 342-348; Łach Stanisław (1906-1983), w: A. Nowak, Słownik biograficzny kapłanów diecezji tarnowskiej 1786-1985, t. 3, Tarnów 2001, s. 156-157; Rocznik diecezji tarnowskiej na rok 1950, dz. cyt., s. 25.

${ }^{64}$ Por. Najwyższe władze diecezjalne. Kuria..., dz. cyt.; A. Nita, Zmarł ks. Franciszek Ozorka - były proboszcz parafii Lisia Góra, http://www.korzeniow.parafia.info.pl/?p=main\&what $=29(5.07 .2017)$.

${ }^{65}$ Por. Ks. Franciszek Mróz, ADT, PM x/8; Mróz Franciszek (1871-1955), w: A. Nowak, Stownik biograficzny..., dz. cyt., t. 3, s. 229. 
Ksiądz Jan Paciorek - urodzony 11 czerwca 1895 roku w Leszczynie, syn Józefa Paciorka i Marii Bębenek. Święcenia kapłańskie przyjął 29 czerwca 1918 roku z rąk biskupa Leona Wałęgi. Wykładowca katechetyki i pedagogiki w Wyższym Seminarium Duchownym w Tarnowie. Szambelan papieski. Sędzia prosynodalny i synodalny Sądu Diecezjalnego w Tarnowie. Zmarł 26 grudnia 1980 roku $^{66}$.

Ksiądz Julian Piskorz - urodzony 3 września 1891 roku w Trzcianie, syn Wojciecha Piskorza i Marii Paciorek. Święcenia kapłańskie przyjął 26 lipca 1914 roku z rąk biskupa Zygmunta Weitza. Doktorat z teologii uzyskał 5 czerwca 1917 roku na Uniwersytecie Leopolda i Franciszka w Innsbrucku. Habilitował się na Uniwersytecie Jagiellońskim 31 lipca 1939 roku. Proboszcz w Nowym Wiśniczu i Jazowsku. Wykładowca teologii pastoralnej i homiletyki w Wyższym Seminarium Duchownym w Tarnowie. Szambelan papieski. Sędzia synodalny Sądu Diecezjalnego w Tarnowie. Zmarł 30 stycznia 1954 roku $^{67}$.

Ksiądz Jan Prysak - urodzony 3 lutego 1911 roku w Sayreville (New Jersey, USA), syn Jana Prysaka i Weroniki Bronikowskiej. Święcenia kapłańskie przyjął 11 sierpnia 1935 roku z rąk biskupa Edwarda Komara. Doktorat z teologii uzyskał w 1938 roku na Uniwersytecie Leopolda i Franciszka w Innsbrucku. Wykładowca języka łacińskiego i liturgiki w Wyższym Seminarium Duchownym w Tarnowie. Sędzia synodalny Sądu Diecezjalnego w Tarnowie. Zmarł 11 maja 1959 roku $^{68}$.

${ }^{66}$ Por. Ks. Jan Paciorek, ADT, PP viI/2; P. Gajda, Diamentowy jubileusz kapłaństwa ks. Prałata Jana Paciorka, „Currenda” 128 (1978), s. 325-326; Paciorek Jan (1895-1980), w: A. Nowak, Słownik biograficzny..., dz. cyt., t. 3, s. 278; A. Paciorek, Paciorek Jan (18951980), w: Stownik polskich teologów katolickich, t. 6, red. L. Grzebień, Warszawa 1983, s. 603-604; Rocznik diecezji tarnowskiej na rok 1944, Tarnów 1944, s. 12; Rocznik diecezji tarnowskiej na rok 1946, Tarnów 1946, s. 14; Rocznik diecezji tarnowskiej na rok 1948, Tarnów 1948, s. 23-24; Rocznik diecezji tarnowskiej na rok 1950, dz. cyt., s. 25.

${ }^{67}$ Por. Ks. Julian Piskorz, ADT, PP Ix/1; Piskorz Julian (1891-1954), w: A. Nowak, Słownik biograficzny..., dz. cyt., t. 1, s. 141-142; Ks. Prałat Dr Julian Piskorz (1891-1954), w: J. Rzepa, Rzut oka..., dz. cyt., s. 42-43; Rocznik diecezji tarnowskiej na rok 1944, dz. cyt., s. 12; Rocznik diecezji tarnowskiej na rok 1946, dz. cyt., s. 14; Rocznik diecezji tarnowskiej na rok 1948, dz. cyt., s. 23; Rocznik diecezji tarnowskiej na rok 1950, dz. cyt., s. 25.

${ }^{68}$ Por. Ks. Jan Prysak, ADT, PP x/6; Prysak Jan (1911-1959), w: A. Nowak, Słownik biograficzny..., dz. cyt., t. 3, s. 334-335; Ks. Profesor Dr Jan Prysak (1911-1959), w: J. Rzepa, Rzut oka..., dz. cyt., s. 47-48; Rocznik diecezji tarnowskiej na rok 1950, dz. cyt., s. 26; Rocznik diecezji tarnowskiej na rok 1959, dz. cyt., s. 26. 
Ksiądz Stanisław Pycior - urodzony 8 marca 1916 roku w Trzcianie, syn Tomasza Pyciora i Barbary Dziedzic. Święcenia kapłańskie przyjął 31 marca 1940 roku z rąk biskupa Edwarda Komara. Doktorat z prawa kanonicznego uzyskał w 1949 roku na Katolickim Uniwersytecie Lubelskim. Wykładowca prawa kanonicznego, języka łacińskiego i niemieckiego w Wyższym Seminarium Duchownym w Tarnowie. Kapitan Wojska Polskiego. Notariusz (mianowany 25 lipca 1949 roku) i wiceoficjał (iuram. 25 kwietnia 1957 roku) Sądu Diecezjalnego w Tarnowie. Zmarł 9 września 1996 roku $^{69}$.

Ksiądz Piotr Rajca - urodzony 8 czerwca 1889 roku w Zalipiu, syn Jana Tomasza Rajcy i Marii Janeczek. Święcenia kapłańskie przyjął 29 czerwca 1913 roku z rąk biskupa Leona Wałęgi. Proboszcz w Ostrowie, Starej Jastrząbce i Jurkowie koło Czchowa. Dziekan dekanatu radomyskiego i tarnowskiego zamiejskiego. Sędzia prosynodalny Sądu Diecezjalnego w Tarnowie - mianowany 11 stycznia 1957 roku. Zmarł 10 sierpnia $1959 \mathrm{roku}^{70}$.

Ksiądz Michał Rec - urodzony 12 maja 1873 roku w Chorzelowie, syn Antoniego Reca i Marii Pietryki. Święcenia kapłańskie przyjął 29 czerwca 1897 roku z rąk biskupa Ignacego Łobosa. Doktorat z teologii uzyskał 19 listopada 1901 roku na Uniwersytecie Wiedeńskim. Prefekt i wicerektor, wykładowca teologii moralnej w Wyższym Seminarium Duchownym w Tarnowie. Szambelan papieski i prałat domowy ojca świętego. Sędzia synodalny Sądu Diecezjalnego w Tarnowie. Zmarł 30 stycznia 1958 roku $^{71}$.

${ }^{69}$ Por. Ks. Stanisław Pycior, ADT, PP x/13; Najwyższe władze diecezjalne. Kuria..., dz. cyt.; M. Tokarz, Pycior Stanisław (1916), w: Najwyższe władze diecezjalne. Kuria..., dz. cyt.; K. Talarek, Ks. Stanisław Pycior, w: Ks. Stanisław Pycior, ADT, dz. cyt.; P. Gajda, Kapelan partyzantów. Śp. Ks. Dr Stanisław Pycior, „Currenda” 146 (1996), s. 511-526; Rocznik diecezji tarnowskiej na rok 1950, dz. cyt., s. 25; Rocznik diecezji tarnowskiej na rok 1959, dz. cyt., s. 26; Rocznik diecezji tarnowskiej na rok 1963, dz. cyt., s. 28; Rocznik diecezji tarnowskiej na rok 1967, dz. cyt., s. 67; Rocznik diecezji tarnowskiej na rok 1972, dz. cyt., s. 46; Schematyzm diecezji tarnowskiej na rok 1977, dz. cyt., s. 69; Schematyzm diecezji tarnowskiej 1983, dz. cyt., s. 50.

${ }^{70}$ Por. Ks. Piotr Rajca, ADT, PP Iv/6; Najwyższe władze diecezjalne. Kuria..., dz. cyt.; Rajca Piotr (1889-1959), w: A. Nowak, Słownik biograficzny kapłanów diecezji tarnowskiej 1786-1985, t. 4, Tarnów 2004, s. 12-13; Rocznik diecezji tarnowskiej na rok 1959, dz. cyt., s. 26.

${ }^{71}$ Por. Ks. Michał Rec, ADT, PR IV/10; Rajca Piotr (1889-1959), w: A. Nowak, Słownik biograficzny..., dz. cyt., t. 4, s. 17-18; Ks. Prałat Dr Michat Rec (1889-1959), w: J. Rzepa, Rzut oka..., dz. cyt., s. 46-47; J. Wołczański, Rec Michał (1889-1959), w: Słownik biograficzny katolicyzmu społecznego w Polsce, t. 3, red. R. Bender, E. Alabrudzińska, Lublin 1995, 
Ksiądz Aleksander Rusin - urodzony 15 stycznia 1894 roku w Tuszymie, syn Andrzeja Rusina i Zofii Ihry. Święcenia kapłańskie przyjął 29 czerwca 1918 roku z rąk biskupa Leona Wałęgi. Proboszcz w Lisiej Górze. Dziekan dekanatu tarnowskiego i tarnowskiego zamiejskiego. Sędzia prosynodalny Sądu Diecezjalnego w Tarnowie - mianowany 24 listopada 1951 roku. Zmarł 29 czerwca 1972 roku $^{72}$.

Ksiądz Stanisław Sroka - urodzony 1 kwietnia 1905 roku w Zabrniu koło Szczucina, syn Walentego Sroki i Katarzyny Krupy. Święcenia kapłańskie przyjął 29 czerwca 1930 roku z rąk biskupa Leona Wałęgi. Doktorat z teologii uzyskał na Uniwersytecie Jana Kazimierza we Lwowie. Długoletni wicekanclerz i kanclerz Kurii Diecezjalnej w Tarnowie. Kanonik gremialny Kapituły Katedralnej w Tarnowie. Szambelan papieski. Sędzia prosynodalny Sądu Diecezjalnego w Tarnowie - mianowany 23 listopada 1959 roku. Zmarł 27 września 1982 roku$^{73}$.

Ksiądz Jakub Stanczykiewicz - urodzony 13 maja 1869 roku w Krzyżu koło Tarnowa, syn Walentego Stanczykiewicza i Józefy Bielińskiej. Święcenia kapłańskie przyjął 21 czerwca 1892 roku z rąk biskupa Ignacego Łobosa. Doktorat z teologii uzyskał w 1897 roku na Uniwersytecie Wiedeńskim. Wykładowca teologii pastoralnej w Wyższym Seminarium Duchownym w Tarnowie. Szambelan papieski. Sędzia synodalny Sądu Diecezjalnego w Tarnowie. Zmarł 29 lipca 1946 roku $^{74}$.

Ksiądz Władysław Szczebak - urodzony 16 września 1929 roku. Święcenia kapłańskie przyjął 9 maja 1954 roku. Doktorat uzyskał w 1995 roku w Instytucie Sztuki Polskiej Akademii Nauk. Prefekt i wykładowca historii sztuki sakralnej w Wyższym Seminarium Duchownym w Tarnowie.

s. 11-12; Rocznik diecezji tarnowskiej na rok 1944, dz. cyt., s. 12; Rocznik diecezji tarnowskiej na rok 1946, dz. cyt., s. 14; Rocznik diecezji tarnowskiej na rok 1948, dz. cyt., s. 23; Rocznik diecezji tarnowskiej na rok 1950, dz. cyt., s. 25.

${ }^{72}$ Por. Ks. Aleksander Rusin, ADT, PR v/6; Najwyższe władze diecezjalne. Kuria..., dz. cyt.; Rusin Aleksander (1894-1918), w: A. Nowak, Słownik biograficzny..., dz. cyt., t. 4, s. 37; Rocznik diecezji tarnowskiej na rok 1959, dz. cyt., s. 26; Rocznik diecezji tarnowskiej na rok 1963, dz. cyt., s. 28; Rocznik diecezji tarnowskiej na rok 1967, dz. cyt., s. 67.

${ }^{73}$ Por. Najwyższe władze diecezjalne. Kuria..., dz. cyt.; Ks. Stanisław Sroka, ADT, PS XVI/14; Sroka Stanisław (1905-1982), w: A. Nowak, Słownik biograficzny..., dz. cyt., t. 1, s. 153-155; Schematyzm diecezji tarnowskiej na rok 1977, dz. cyt., s. 56.

${ }^{74}$ Por. Ks. Jakub Stanczykiewicz, ADT, Ps VIII/11; Stanczykiewicz Jakub (1869-1946), w: A. Nowak, Słownik biograficzny..., dz. cyt., t. 4, s. 96-97; Rocznik diecezji tarnowskiej na rok 1944, dz. cyt., s. 12; Rocznik diecezji tarnowskiej na rok 1946, dz. cyt., s. 14. 
Długoletni dyrektor Muzeum Diecezjalnego w Tarnowie. Diecezjalny konserwator zabytków. Przewodniczący diecezjalnej Komisji Sztuki Kościelnej. Kapelan Jego Świątobliwości. Sędzia prosynodalny Sądu Diecezjalnego w Tarnowie - mianowany 13 marca 1973 roku $^{75}$.

Ksiądz Kazimierz Szwarga - urodzony 4 stycznia 1939 roku w Brzanie koło Bobowej, syn Józefa Szwargi i Marii Śliwy. Święcenia kapłańskie przyjął 24 czerwca 1962 roku z rąk arcybiskupa Jerzego Ablewicza. Doktorat z teologii uzyskał w 1970 roku na Katolickim Uniwersytecie Lubelskim. Notariusz Kurii Diecezjalnej w Tarnowie. Dyrektor Archiwum Diecezjalnego w Tarnowie. Dyrektor Domu Księży Emerytów przy ulicy Starodąbrowskiej w Tarnowie. Kapelan Jego Świątobliwości. Sędzia prosynodalny Sądu Diecezjalnego w Tarnowie - mianowany 13 marca 1973 roku. Zmarł 16 kwietnia 2010 roku $^{76}$.

Ksiądz Stefan Tabor - członek Kongregacji Oratorium Świętego Filipa Neri, związany w sposób szczególny ze wspólnotami w Tarnowie i Świętej Górze pod Gostyniem. Autor kilku monografii (Krótki zarys historii cudownego obrazu Matki Boskiej Świętogórskiej, Kościót i cudowny obraz Matki Boskiej na Świętej Górze, Kościół oo. Oratorianów w Gostyniu. Na pamiątkę koronacji cudownego obrazu Matki Boskiej). Sędzia prosynodalny Sądu Diecezjalnego w Tarnowie - iuram. 4 marca 1947 roku $^{77}$.

Ksiądz Michał Tokarz - urodzony 30 listopada 1915 roku w Kolbuszowej Górnej, syn Józefa Tokarza i Wiktorii Wiktor. Święcenia kapłańskie przyjął 8 czerwca 1941 roku z rąk biskupa Edwarda Komara. Doktorat z teologii uzyskał 26 stycznia 1949 roku na Uniwersytecie Jagiellońskim w Krakowie. Wikariusz w Radłowie i Bochni. Katecheta w Sędziszowie i Dąbrowie Tarnowskiej. Duszpasterz wśród Polaków w Brazylii. Obrońca węzła małżeńskiego, sędzia prosynodalny (mianowany 21 listopada 1959 roku) i sędzia audytor (mianowany 28 stycznia 1966 roku) w Sądzie Diecezjalnym w Tarnowie. Zmarł 9 sierpnia 1998 roku $^{78}$.

75 Por. Najwyższe władze diecezjalne. Kuria..., dz. cyt.

${ }^{76}$ Por. Najwyższe władze diecezjalne. Kuria..., dz. cyt.; M. Podgórski, Zmarli kapłani. Kapłani zmarli w 2010 roku. Ks. dr Kazimierz Szwarga, http://www.currenda.diecezja.tarnow.pl/archiwum/o1-11/art-37.php (28.09.2018).

77 Por. Najwyższe władze diecezjalne. Kuria..., dz. cyt.; J. Poprawa, Konwikt na Świętej Górze (1920-1951), „Nowa Gazeta Gostyńska” 27 (2008), s. 13.

${ }^{78}$ Por. Ks. Michał Tokarz, ADT, Pт III/8; Najwyższe władze diecezjalne. Kuria..., dz. cyt.; Rocznik diecezji tarnowskiej na rok 1959, dz. cyt., s. 27; Rocznik diecezji tarnowskiej na rok 
Ksiądz Władysław Węgiel - urodzony 3 sierpnia 1900 roku w Ćwikowie koło Olesna, syn Józefa Węgla i Józefy Kądzielawy. Święcenia kapłańskie przyjął 29 czerwca 1925 roku z rąk biskupa Leona Wałęgi. Doktorat z teologii uzyskał 20 lipca 1929 roku na Papieskim Uniwersytecie Gregoriańskim. Prefekt, wicerektor, rektor, wykładowca historii Kościoła, patrologii i homiletyki w Wyższym Seminarium Duchownym w Tarnowie. Szambelan papieski i prałat honorowy ojca świętego. Sędzia prosynodalny Sądu Diecezjalnego w Tarnowie - mianowany dwukrotnie: 19 kwietnia 1937 roku oraz 6 marca 1947 roku. Zmarł 19 czerwca 1976 roku $^{79}$.

Ksiądz Tomasz Włoch - urodzony 21 lutego 1868 roku w Żabnie, syn Jakuba Włocha i Marii Uramowicz. Święcenia kapłańskie przyjął 21 czerwca 1892 roku z rąk biskupa Ignacego Łobosa. Doktorat z teologii uzyskał 20 stycznia 1897 roku na Uniwersytecie Wiedeńskim. Wykładowca teologii dogmatycznej i Starego Testamentu w Wyższym Seminarium Duchownym w Tarnowie. Dziekan dekanatu tarnowskiego zamiejskiego. Szambelan papieski. Sędzia synodalny Sądu Diecezjalnego w Tarnowie. Zmarł 13 listopada 1956 roku $^{80}$.

Ksiądz Stanisław Wróbel - urodzony 4 października 1879 roku w Proszówkach, syn Wawrzyńca Wróbla i Marii Florek. Święcenia kapłańskie przyjął 29 czerwca 1902 roku z rąk biskupa Leona Wałęgi. Doktorat z teologii uzyskał w 1906 roku na Papieskim Uniwersytecie Gregoriańskim w Rzymie. Wykładowca filozofii i apologetyki w Wyższym Seminarium Duchownym w Tarnowie. Szambelan papieski. Sędzia synodalny Sądu Diecezjalnego w Tarnowie. Zmarł 9 sierpnia 1954 roku $^{81}$.

1963, dz. cyt., s. 28; Rocznik diecezji tarnowskiej na rok 1967, dz. cyt., s. 67; Rocznik diecezji tarnowskiej na rok 1972, dz. cyt., s. 46; Schematyzm diecezji tarnowskiej na rok 1977, dz. cyt., s. 69; Schematyzm diecezji tarnowskiej 1983, dz. cyt., s. 50.

79 Por. Ks. Władysław Wegiel, ADT, PW VIII/14; Wegiel Władysław (1900-1976), w: A. Nowak, Stownik biograficzny..., dz. cyt., t. 1, s. 164-165; P. Bednarczyk, Śp. Ks. Rektor Władysław Wegiel, „Currenda” 126 (1976), s. 251-259; Ks. Prałat Dr Władysław Wegiel (190o-1976), w: J. Rzepa, Rzut oka..., dz. cyt., s. 61-63; M. Szczerba, Życie i działalność Księdza Władysława Węgla (19oo-1976), Tarnów 1997 [maszynopis].

${ }^{80}$ Por. Ks. Tomasz Włoch, ADT, PW x/3; Włoch Tomasz (1868-1956), w: A. Nowak, Słownik biograficzny..., dz. cyt., t. 4, s. 207-208; Rocznik diecezji tarnowskiej na rok 1944, dz. cyt., s. 12; Rocznik diecezji tarnowskiej na rok 1946, dz. cyt., s. 14; Rocznik diecezji tarnowskiej na rok 1948, dz. cyt., s. 23.

${ }^{81}$ Por. Ks. Stanisław Wróbel, ADT, PW XI/13; Wróbel Stanisław (1879-1954), w: A. Nowak, Słownik biograficzny..., dz. cyt., t. 4, s. 225-226; Ks. Prałat Dr Stanisław Wróbel (1879-1954), 
Paweł Lewandowski

Ksiądz Stefan Mateusz Zalesieński - urodzony 22 czerwca 1899 roku w Moszczenicy Niżnej, syn Marcina Wąchały i Heleny Franczyk. Święcenia kapłańskie przyjął 29 czerwca 1922 roku z rąk biskupa Leona Wałęgi. Doktorat z prawa kanonicznego uzyskał 10 czerwca 1925 roku w Collegium Angelicum w Rzymie. Proboszcz w Biegonicach. Notariusz dekanatu starosądeckiego. Szambelan papieski. Wiceoficjał (mianowany w 1950 roku) i oficjał (mianowany 10 kwietnia 1957 roku) Sądu Diecezjalnego w Tarnowie. Zmarł 17 lipca 1972 roku $^{82}$.

\section{Zakończenie}

1. Zadaniem sędziego kościelnego jest rozpatrywanie, czyli wyjaśnianie spraw wnoszonych do trybunału, oraz ich rozstrzyganie, czyli wydawanie decyzji sędziowskich na podstawie określonych przepisów prawa oraz wiedzy i sumienia sędziego.

2. Na mocy własnego i wyłącznego prawa sądownictwu kościelnemu podlegają: sprawy o rzeczy duchowe lub ściśle z nimi złączone; przekroczenie ustaw kościelnych, a także wszystkie sprawy związane z grzechem, $\mathrm{w}$ takim zakresie, $\mathrm{w}$ jakim dotyczy to określenia winy i nałożenia kar kościelnych; sprawy cywilne i karne podmiotów cieszących się przywilejem sądu kościelnego.

3.Zgodnie z dyspozycjami zawartymi w CIC 1917 w każdej diecezji należy ustanowić od 4 do 12 sędziów synodalnych lub prosynodalnych z władzą delegowaną przez miejscowego ordynariusza, którą otrzymują $\mathrm{z}$ chwilą mianowania na synodzie diecezjalnym lub poza nim.

w: J. Rzepa, Rzut oka..., dz. cyt., s. 43-44; Rocznik diecezji tarnowskiej na rok 1944, dz. cyt., s. 12; Rocznik diecezji tarnowskiej na rok 1946, dz. cyt., s. 14; Rocznik diecezji tarnowskiej na rok 1948, dz. cyt., s. 23; Rocznik diecezji tarnowskiej na rok 1950, dz. cyt., s. 25.

${ }^{82}$ Por. Ks. Stefan Zalesieński, ADT, PZ IV/10; S. Pycior, Zalesieński Stefan (1899-1972), w: Najwyższe władze diecezjalne. Kuria..., dz. cyt.; Zalesieński Stefan (1899-1972), w: A. Nowak, Stownik biograficzny..., dz. cyt., t. 1, s. 170-171; J. Rzepa, Ks. Prałat Dr Stefan Zalesieński (1899-1972), „Currenda” 132 (1982), s. 151-152; J. Rzepa, Ks. Prałat Dr Stefan Zalesieński (1899-1972), w: J. Rzepa, Rzut oka..., dz. cyt., s. 56-57; Rocznik diecezji tarnowskiej na rok 1959, dz. cyt., s. 26; Rocznik diecezji tarnowskiej na rok 1963, dz. cyt., s. 28; Rocznik diecezji tarnowskiej na rok 1967, dz. cyt., s. 67; Rocznik diecezji tarnowskiej na rok 1972, dz. cyt., s. 46; Schematyzm diecezji tarnowskiej na rok 1977, dz. cyt., s. 69; P. Bednarczyk, Kazanie z okazji wprowadzenia do bazyliki zwłok śp. Ks. Prałata Stefana Zalesieńskiego (19 VII 1972), w: Ks. Stefan Zalesieński, ADT, dz. cyt. 
4. Podstawowymi źródłami kościelnego prawa procesowego, na których podstawie sędziowie pierwszej instancji Sądu Diecezjalnego w Tarnowie orzekali w latach 1945-1983, były CIC 1917 i PME.

5. Na przestrzeni lat $1945-1983 \mathrm{w}$ procesach prowadzonych w pierwszej instancji Sądu Diecezjalnego w Tarnowie orzekało 38 sędziów. Jak wskazuje kwerenda biograficzna, urząd sędziego w pierwszej instancji Sądu Diecezjalnego w Tarnowie pełniły osoby gruntownie wykształcone, po specjalistycznych studiach - nierzadko prawniczych - odbytych w Polsce i za granicą, o szerokich horyzontach umysłowych, ze znajomością języków obcych, z dużym doświadczeniem, prawowierne i pobożne. 
